\title{
Peri- and postmenopause-diagnosis and interventions interdisciplinary S3 guideline of the association of the scientific medical societies in Germany (AWMF 015/062): short version
}

\author{
Olaf Ortmann ${ }^{1}$ (D) Maria J. Beckermann ${ }^{2}$ - Elisabeth C. Inwald ${ }^{1} \cdot$ Thomas Strowitzki $^{3} \cdot$ Eberhard Windler $^{4}$. \\ Clemens Tempfer $^{5}$. For the guideline group
}

Received: 8 May 2020 / Accepted: 4 July 2020 / Published online: 13 July 2020

(c) The Author(s) 2020

\begin{abstract}
This short version of the interdisciplinary S3 guideline "Peri- and Postmenopause-Diagnosis and Interventions" is intended as a decision-making instrument for physicians who counsel peri- and postmenopausal women. It is designed to assist daily practice. The present short version summarizes the full version of the guideline which contains detailed information on guideline methodology, particularly regarding the critical appraisal of the evidence and the assignment of evidence levels. The statements and recommendations of the full version of the guideline are quoted completely in the present short version including levels of evidence (LoE) and grades of recommendation. The classification system developed by the Centre for Evidence-based Medicine in Oxford was used in this guideline.
\end{abstract}

Keywords Perimenopause $\cdot$ Postmenopause $\cdot$ Hormone replacement therapy $\cdot$ Diagnosis $\cdot$ Treatment $\cdot$ Risk communication

\section{Introduction}

Peri- and postmenopausal women often seek medical assistance because of climacteric symptoms (e.g. vasomotoric symptoms). They want information (a) about the

See "Appendix" for guideline group.

Electronic supplementary material The online version of this article (https://doi.org/10.1007/s00404-020-05682-4) contains supplementary material, which is available to authorized users.

Olaf Ortmann

olaf.ortmann@klinik.uni-regensburg.de

1 Department of Gynecology and Obstetrics, University Medical Center Regensburg, Landshuter Straße 65, 93053 Regensburg, Germany

2 Frauenärztliche Gemeinschaftspraxis, Köln, Germany

3 Department of Gynecological Endocrinology and Fertility Disorders, University Women's Hospital, Heidelberg, Germany

4 Endocrinology and Metabolism of Ageing, University Medical Center Hamburg-Eppendorf, Hamburg-Eppendorf, Germany

5 Department of Obstetrics and Gynecology, Ruhr-University Bochum, Bochum, Germany physiological changes during the menopausal transition period and (b) ways to alleviate their symptoms to improve their quality of life. During peri- and postmenopause, symptoms may change. Dysfunctions and diseases may develop that may or may not depend on the changes of sex hormones. Perimenopausal women often ask for information about how to prevent diseases that are typically associated with the perimenopausal transition and the postmenopause. The current S3 guideline, Peri- and Postmenopause-Diagnosis and Interventions' is based on the previous interdisciplinary S3 guideline, Hormone therapy in perimenopause and postmenopause' [1, Appendix]. The authors of the current S3 guideline intended to take a broader spectrum of issues of the peri- and postmenopause into account and provide evidence-based recommendations to counsel women in this period of life. 


\section{Diagnosis and treatment}

\begin{tabular}{|c|c|c|}
\hline \multicolumn{3}{|c|}{ Evidence-based recommendation } \\
\hline $\begin{array}{l}\text { Level of Evidence } \\
\text { LLA }\end{array}$ & $\begin{array}{l}\text { Grade of recommen- } \\
\text { dation A }\end{array}$ & $\begin{array}{l}\text { Degree of consen- } \\
\text { sus++ }\end{array}$ \\
\hline \multicolumn{3}{|c|}{$\begin{array}{l}\text { Peri- and Postmenopause in women aged } 45 \text { or older should be } \\
\text { diagnosed based on clinical parameters }\end{array}$} \\
\hline \multicolumn{3}{|c|}{ Evidence-based recommendation } \\
\hline $\begin{array}{l}\text { Level of Evidence } \\
\text { LLA }\end{array}$ & $\begin{array}{l}\text { Grade of recommen- } \\
\text { dation A }\end{array}$ & $\begin{array}{l}\text { Degree of consen- } \\
\text { sus++ }\end{array}$ \\
\hline \multicolumn{3}{|c|}{$\begin{array}{l}\text { FSH should be used to diagnose peri- and postmenopause only in } \\
\text { women between } 40 \text { and } 45 \text { years with climacteric symptoms or } \\
\text { in women under the age of } 40 \text { years with suspected indicators of } \\
\text { premature ovarian insufficiency }\end{array}$} \\
\hline
\end{tabular}

The different phases of the menopausal transition can be mainly diagnosed by clinical criteria. Hormone measurements are usually not necessary $[1,2]$. The following terms should be used for healthy women older than 45 years who have climacteric symptoms without laboratory tests:

- Perimenopause-women with irregular menstrual cycles and possibly vasomotor symptoms.

- Postmenopause-women without a menstrual bleeding for at least 1 year in the absence of interventions which may cause amenorrhea (e.g. oral contraceptives).

- Peri-/postmenopause-women after hysterectomy with vasomotor symptoms. In women who are using hormone replacement therapy (HRT), it may be difficult to define the menopausal status.

In women older than 45 years, measurements of anti-Müllerian hormone, inhibin A, inhibin B, antral follicle count or ovarian volume should not be used to diagnose peri- or postmenopause. Follicle stimulating hormone (FSH) measurement may be used in women between 40 and 45 years with climacteric symptoms or irregular menstrual cycles and in women younger than 40 years with suspected premature ovarian insufficiency $[1,2]$.

\section{Symptoms}

Vasomotor symptoms such as hot flushes and night sweats are the most common symptoms of the climacteric syndrome in peri- and postmenopausal women. Other symptoms such as sleep disturbances, mood swings, anxiety, and sexual impairment may also be associated with the peri- and postmenopause. In contrast to the vasomotoric symptoms, it is not clear whether the other symptoms are caused by hormonal changes. Loss of estradiol is the main cause of the climacteric syndrome, but the exact role of serum and tissue level changes of estradiol and other hormones such as androgens and gonadotropins is unclear.

Frequency and duration of all climacteric symptoms vary considerably and may be influenced by a number of factors such as general health and well-being, socioeconomic status, cultural influence, and other factors. The prevalence of hot flushes has been reported to be between 14 and 51\% among premenopausal women, about $50 \%$ among perimenopausal women, and between 30 and $80 \%$ among postmenopausal women [3]. The median duration of hot flushes is 7.4 years. Longer durations typically occur when climacteric symptoms already develop in the premenopause [4].

\section{Information}

Peri- and postmenopausal women should be informed about the phases of peri- and postmenopause, the diagnosis, typical symptoms (vasomotor symptoms, sleep disorders, mood changes, urogenital symptoms, sexual impairment, changes in lifestyle and other measures which may affect health and well-being). In addition, they should be informed about the benefits and risks of different treatments strategies and the long-term effects of peri- and postmenopause on female health. Peri- and postmenopausal women should also be informed about different treatment options such as hormonal interventions, non-hormonal interventions and non-pharmacologic interventions.

\section{Therapeutical interventions}

\begin{tabular}{l}
\hline \begin{tabular}{l} 
Evidence-based recommendation \\
\hline $\begin{array}{l}\text { Level of Evidence 1a } \\
\text { dation A }\end{array}$
\end{tabular} \\
$\begin{array}{l}\text { Women with vasomotor symptoms should be offered hormone } \\
\text { replacement therapy (HRT) after information about short- (up to } \\
5 \text { years) and long-term risks and benefits. Women with an intact } \\
\text { uterus may receive estradiol replacement therapy with an appro- } \\
\text { priate progestin component (EPT), women after hysterectomy } \\
\text { may receive estradiol replacement therapy (ET) only }\end{array}$ \\
\hline
\end{tabular}


Evidence-based recommendation

Level of Evidence 3 Grade of recommen- Degree of consendation $\mathrm{A} \quad$ sus ++

Serotonin reuptake inhibitors (SSRIs), serotonin noradrenaline reuptake inhibitors (SNRIs), clonidine, and gabapentin should not be offered as treatment of first choice for the treatment of vasomotor symptoms

Evidence-based recommendation

Level of Evidence 1b Grade of recommen- Degree of consendation $0 \quad$ sus ++

Cognitive behavioural therapy (CBT), isoflavones, and cimicifuga preparations may be used to treat vasomotor symptoms

* See "Appendix" for dissenting opinion of the GPT

\section{Vasomotoric symptoms}

Estradiol is the most efficient means of therapy of climacteric symptoms. Therefore, HRT should be offered all women with moderate to severe climacteric symptoms with significant impairment of their quality of life. For women with an intact uterus, EPT is the most efficient treatment of vasomotoric symptoms. Hysterectomized women should only receive ET. The progestin component of EPT can be applied cyclically or continuously. Potent progestins such as synthetic progestins should be used for at least 10-12 days per month. Shorter treatment periods, or the use of natural progesterone and dydrogesterone instead of synthetic progestins may increase the risk of endometrial hyperplasia and endometrial cancer. One must consider that different HRT preparations or routes of application have different risk profiles. Transdermal application may have a better risk-benefit ratio and should be preferred over oral preparations. Women who desire phytotherapy should be informed that numerous preparations exist, and that the safety of these preparations is often unclear. In addition, combinations of different phytotherapy compounds may have different effects and may interact with concurrent medications [1,2].

\section{Changes of sexual function}

\begin{tabular}{lll}
\hline Evidence-based recommendation & \\
\hline Level of Evidence 1b & $\begin{array}{l}\text { Grade of recommen- } \\
\text { dation } 0\end{array}$ & $\begin{array}{l}\text { Degree of consen- } \\
\text { sus }++\end{array}$ \\
\hline
\end{tabular}

Peri- and postmenopausal women with loss of libido can be offered testosterone treatment after psychosexual exploration and when HRT has not been efficient. They should be informed about offlabel use
Peri- and postmenopausal women may observe changes in sexual function. They should be asked about signs of vaginal atrophy such as dyspareunia. Loss of libido is common in ageing women. Low levels of estrogen and testosterone may be associated with loss of libido. However, there is no strict association between sex hormone levels and libido as reasons for loss of libido are complex. A psychotherapeutic intervention may be beneficial. Treatment with testosterone may be considered when HRT was not efficient for improving libido. Moisturizers and lubricants may be used alone or in addition to vaginal estrogen preparations. All these interventions are usually sufficient to reduce vaginal symptoms such as dryness, pain on intercourse or vaginal discharge. When estrogens are used for the treatment of vaginal dryness, estriol (E3)-containing preparations should be preferred. E3 may be used efficiently in low or ultra-low doses. The dosage may be increased if symptoms are not relieved. When treatment is terminated, symptoms typically re-occur. Side effects of vaginal ET are rare $[1,2]$.

\section{Urogenital atrophy}

\begin{tabular}{|c|c|c|}
\hline \multicolumn{3}{|c|}{ Evidence-based recommendation } \\
\hline Level of Evidence $1 \mathrm{~b}$ & $\begin{array}{l}\text { Grade of recommen- } \\
\text { dation A }\end{array}$ & $\begin{array}{l}\text { Degree of consen- } \\
\text { sus }+++\end{array}$ \\
\hline
\end{tabular}

\section{Starting and stopping HRT}

After starting HRT, women should consult their gynaecologist regularly (initially after 3 months) to monitor treatment effectiveness and tolerability of the therapy. Women should be advised to consult their gynaecologist in case of atypical bleeding. Modification of HRT has to be considered for several reasons during different phases of peri- and postmenopause. When treatment is well tolerated and no pathological symptoms occur, yearly gynecologic consultations are appropriate. Vaginal ultrasound examinations and endometrial thickness measurements should not be used routinely during HRT [5].

If it is determined that HRT should be stopped, two options can be offered: gradually reducing HRT or ceasing immediately. Gradually reducing may limit recurrence of symptoms in the short term. Whichever method is chosen, it has no influence on the recurrence rate of symptoms in the longer term. 


\section{Urogynecology}

\section{Urinary incontinence}

\begin{tabular}{|c|c|c|}
\hline \multicolumn{3}{|c|}{ Evidence-based statement } \\
\hline Level of Evidence 1a & & Degree of consensus ++ \\
\hline \multicolumn{3}{|c|}{$\begin{array}{l}\text { Vaginal ET may improve urinary incontinence in postmenopausal } \\
\text { women }\end{array}$} \\
\hline \multicolumn{3}{|c|}{ Evidence-based recommendation } \\
\hline Level of Evidence 1a & $\begin{array}{l}\text { Grade of recommen- } \\
\text { dation A }\end{array}$ & $\begin{array}{l}\text { Degree of consen- } \\
\text { sus }++\end{array}$ \\
\hline \multicolumn{3}{|c|}{$\begin{array}{l}\text { Patients should be informed before systemic ET or EPT that these } \\
\text { therapies may lead to occurrence or worsening of urinary incon- } \\
\text { tinence }\end{array}$} \\
\hline
\end{tabular}

\begin{tabular}{lll}
\hline Evidence-based recommendation & \\
\hline Level of Evidence 1a & $\begin{array}{l}\text { Grade of recommen- } \\
\text { dation A }\end{array}$ & $\begin{array}{l}\text { Degree of consen- } \\
\text { sus }++\end{array}$ \\
\hline
\end{tabular}

Postmenopausal women with urinary incontinence should be offered pelvic floor training and vaginal ET

Randomised controlled trials have shown that in women with urinary incontinence, vaginal ET leads to significant improvements compared to placebo. However, a significantly higher prevalence of incontinence was documented when ET was applied systemically. Specifically, prevalence of urinary incontinence was doubled compared to placebo. EPT also leads to increases of urinary incontinence. However, the effect was smaller than in ET users $[6,11]$.

\section{Overactive bladder}

Evidence-based statement

Level of Evidence $1 \mathrm{~b}$

Degree of consensus +++

Systemic HRT may lead to worsening of urinary incontinence.

Women with overactive bladder may be offered vaginal ET

\begin{tabular}{lll}
\hline Evidence-based recommendation & \\
\hline Level of Evidence 1b & $\begin{array}{l}\text { Grade of recommen- } \\
\text { dation } 0\end{array}$ & $\begin{array}{l}\text { Degree of consen- } \\
\text { sus }++\end{array}$ \\
\hline
\end{tabular}

After exclusion of urological diseases, women with symptoms of urgency and frequency may be offered local ET

\section{Urinary tract infections}

\begin{tabular}{l}
\hline $\begin{array}{l}\text { Evidence-based statement } \\
\text { Level of Evidence } 2 \mathrm{~b}\end{array}$ \\
$\begin{array}{l}\text { Changes in the vaginal milieu of postmenopausal women may pre- } \\
\text { dispose to urinary tract infection, especially in older women }\end{array}$ \\
\hline $\begin{array}{l}\text { Evidence-based recommendation } \\
\text { Level of Evidence 2a } \begin{array}{l}\text { Grade of recommen- } \\
\text { dation B }\end{array}\end{array}$ \\
$\begin{array}{l}\text { Regree of consen- } \\
\text { sus }++\end{array}$ \\
preferably be treated with vaginal ET instead of antibiotics
\end{tabular}

Two small studies have demonstrated that vaginal ET reduced the frequency of urinary tract infections. Oral ET did not lead to a reduction of recurrent urinary tract infections $[6,8,12,16]$.

\section{Cardiovascular disease}

Evidence-based recommendation

Level of Evidence 2b Grade of recommen- Degree of consendation B

sus ++

The risk for cardiovascular disease in peri- and postmenopausal women varies depending on their risk profile. These risk factors should be controlled optimally to exclude contraindications for HRT. Therefore, cardiovascular risk factors have to be identified and treated before HRT is initiated

Because of the various limitations of the trials, mainly the WHI, statements and recommendations on the effects of HRT on cardiovascular diseases are based on a moderate level of evidence. Large randomized intervention trials have shown no general protection against cardiovascular diseases by HRT but indicate a neutral or even negative effect of HRT in postmenopausal women [17]. The analyses of data including recent studies indicate the need for caution, but individualized treatment may have little risk or even cardiovascular 
benefit. The transdermal application has advantages over the oral form [18]. In any case, the prerequisite seems to be the control of the conventional risk factors for cardiovascular events such as heart attack and stroke. Regardless of the study results, previous vascular events may be contraindications for HRT [1, 2].

\section{Thromboembolism}

Evidence-based recommendation

\begin{tabular}{lll}
\hline Level of Evidence 2a & $\begin{array}{l}\text { Grade of recommen- } \\
\text { dation A }\end{array}$ & $\begin{array}{l}\text { Degree of consen- } \\
\text { sus }++\end{array}$ \\
\hline
\end{tabular}

Women should be informed that risk of thromboembolism is higher during oral compared to transdermal ET and EPT

The highest vascular risks of oral HRT are venous thrombosis and thromboembolism $[1,2,19,21]$. ET and EPT double the risk by about two cases per 1000 women per year [22, 25]. Estrogens and progestogens have thrombogenic effects that are dose dependent and substance specific, which are more pronounced in the initial phase of therapy and increase with age, weight and genetic predisposition [20,21]. With low-dose transdermal therapy, there was no evidence of an increased risk of thromboembolism probably due to the lack of a first-pass effect in the liver [19,21].

\section{Cerebrovascular events}

\begin{tabular}{|c|c|c|}
\hline \multicolumn{3}{|c|}{ Evidence-based recommendation } \\
\hline Level of Evidence $2 b$ & $\begin{array}{l}\text { Grade of recommen- } \\
\text { dation } \mathrm{A}\end{array}$ & $\begin{array}{l}\text { Degree of consen- } \\
\text { sus }++\end{array}$ \\
\hline
\end{tabular}

Ischemic strokes are the second most common and because of possible persistent disabilities very serious risk of oral HRT $[2,18,19,26]$. In absolute numbers, the risk increases by 1 case per 1000 women per year during oral ET or EPT intake $[22,27,28]$. An increase in the risk of stroke may be avoidable using transdermal HRT up to a dose of $50 \mu \mathrm{g}$ $[1,2]$.

\section{Coronary heart disease}

\begin{tabular}{l}
\hline \begin{tabular}{l} 
Evidence-based recommendation \\
\hline $\begin{array}{l}\text { Level of Evidence 2b Grade of recommen- } \\
\text { dation A }\end{array}$ \\
$\begin{array}{l}\text { Wegree of consen- } \\
\text { sus }++\end{array}$ \\
diovascular risk or has only a minor effect. ET does not increase \\
cardiovascular risk or may even reduce it. HRT is not appropri- \\
ate for the primary or secondary prevention of coronary heart \\
disease. HRT should be started before the age of 60 years for the \\
treatment of climacteric symptoms
\end{tabular} \\
\hline
\end{tabular}

Neither ET nor EPT have significant influences on the risks for coronary heart disease in primary and secondary prevention [17, 22, 23, 25]. However, HRT initiated within the first 10 years after menopause appears to be associated with a lower coronary event rate, while starting 20 years or more after menopause significantly increases the risk $[1,2,19$, 25].

\section{Osteoporosis}

Evidence-based statement

$\overline{\text { Level of Evidence 1a } \quad \text { Degree of consensus }+++}$

HRT significantly reduces the risk for osteoporotic fractures

\begin{tabular}{l}
\hline Evidence-based statement \\
\hline Level of Evidence 2a Degree of consensus ++ \\
\hline The reduction of osteoporotic fracture risk by HRT is independent \\
of treatment duration (even treatment duration of less than 1 year \\
leads to reduction of the risk of osteoporotic fractures) and age at \\
initiation of HRT. In addition, risk reduction seems to persist after \\
stopping HRT
\end{tabular}

\section{Prevention}

Excessive weight reduction leads to an increased risk for atraumatic fractures. A body mass index below 20 should be avoided. Consequently, weight gain is associated with reduced risk of atraumatic fractures. Weight gain above a body mass index of 35 should be avoided. Exercise and sufficient intake of calcium and vitamin D is recommended [1, $2,29,32]$. 


\section{Treatment}

A number of therapies are licensed for the treatment of osteoporosis: estrogen (in combination with progestin in non-hysterectomised women), bisphosphonates, selective estrogen receptor modulators (SERMs), and a human monoclonal antibody against the RANK ligand (Denosumab) and parathyroid hormone (teriparatid). The efficiency of EPT or ET for primary prevention of osteoporotic factors has been demonstrated in observational studies and randomized controlled trials. The current version of the S3 Guideline of the German Association of Osteology (DVO) recommends that prevention or treatment of osteoporosis by HRT is feasible when women have concurrent climacteric symptoms or do not tolerate or have contraindications against licensed treatments for the prevention or treatment of osteoporosis $[1,2$, 29, 32].

The reduction of fractures by HRT is independent of the duration of HRT and the age at treatment initiation. In addition, the risk reducing effect of HRT seems to persist at a lower level after its termination. Since osteoporosis is a chronic disease, treatment is usually performed for longer durations depending on the assumed baseline risk for fractures. The mean duration is 3-4 years. In accordance to the results of the WHI, the following risk reducing effects can be expected: -23 fractures per 1000 HRT users (confidence interval [CI] 10-33), - 20 non-vertebral fractures per 1000 HRT users (CI 6-30), -8 vertebral fractures per 1000 HRT users (CI -18 to +9$),-0$ hip fractures per 1000 HRT users (CI -10 to +4$),-36$ wrist fractures per 1000 HRT users (CI 19-43) [1, 2]. In women with premature ovarian insufficiency, HRT or oral contraceptives should be used until the age of natural menopause to prevent osteoporosis and osteoporotic fractures.

\section{Dementia, depression and mood changes}

\begin{tabular}{lll}
\hline Evidence-based recommendation & \\
\hline $\begin{array}{l}\text { Level of Evidence } \\
\text { LLA }\end{array}$ & $\begin{array}{l}\text { Grade of recommen- } \\
\text { dation A }\end{array}$ & $\begin{array}{l}\text { Degree of consen- } \\
\text { sus }+++\end{array}$ \\
\hline
\end{tabular}

Peri- and postmenopausal women should be informed that it is unclear whether HRT before the age of 65 has an influence on the risk of dementia.Peri- and postmenopausal women should be informed that it is unclear whether HRT before the age of 65 has an influence on the risk of dementia

\begin{tabular}{|c|c|c|}
\hline \multicolumn{3}{|c|}{ Evidence-based recommendation } \\
\hline $\begin{array}{l}\text { Level of Evidence } \\
\text { LAA }\end{array}$ & $\begin{array}{l}\text { Grade of recommen- } \\
\text { dation A }\end{array}$ & $\begin{array}{l}\text { Degree of consen- } \\
\text { sus }++\end{array}$ \\
\hline \multicolumn{3}{|c|}{$\begin{array}{l}\text { Pharmacological treatment of depression in perimenopausal } \\
\text { women should be used according to current treatment guidelines. } \\
\text { Currently, there is no evidence indicating that the efficacy of anti- } \\
\text { depressant medications varies according to menopausal status. } \\
\text { There is insufficient evidence to recommend HRT or psychother- } \\
\text { apy for the treatment of perimenopausal depression }\end{array}$} \\
\hline
\end{tabular}

There are no data with strong evidence for an increase for the risk or a beneficial effect on dementia in women using HRT before the age of 65 years [2]. In the WHI, it was demonstrated that HRT when initiated after the age of 65 years increased the risk for dementia significantly [22]. HRT may be considered for mood changes which develop or worsen during the menopausal transition. There is no evidence for an effect of selective serotonin reuptake inhibitors (SSRI) or selective noradrenalin reuptake inhibitors (SNRI) on menopausal mood changes [2].

There is no convincing data for the efficacy of HRT in prevention or treatment for depression in peri- und postmenopausal women. Women with depression should be treated according to current treatment guidelines [33, 34].

\section{HRT and cancer risk}

\section{HRT and breast cancer risk}

Evidence-based recommendation

\begin{tabular}{lll}
\hline Level of Evidence 1a & $\begin{array}{l}\text { Grade of recommen- } \\
\text { dation A }\end{array}$ & $\begin{array}{l}\text { Degree of consen- } \\
\text { sus }++\end{array}$
\end{tabular}

Women considering HRT should be informed that HRT (EPT/ET) may lead to a small or no increased risk of breast cancer. Breast cancer risk depends on HRT formulations and treatment duration and is reduced after the end of treatment

\section{EPT}

EPT may increase breast cancer risk. This was shown in a number of meta-analyses that included observational studies as well as randomized controlled trials (RCTs). In the randomized Women's Health Initiative (WHI) trial, EPT led to an increased relative risk of breast cancer of 1.26 with 8 additional cases per 10,000 women per year [22,35]. Cohort studies have shown that continuous combined EPT leads to higher increases in breast cancer risk than sequential EPT. 
RCTs and observational studies demonstrated that current users of EPT have an increased breast cancer risk.

However, this risk is reduced after stopping HRT. When HRT was initiated at or around the age of menopause, breast cancer risk increases were higher than in women who initiated HRT more than 5 years after menopause. EPT-containing progesterone leads to smaller increases of breast cancer risk compared to EPT-containing synthetic progestins [36]. However, progesterone has a smaller anti-proliferative effect on the endometrium than synthetic progestins. In the WHI, study breast cancer mortality was increased in HRT users in the short term, but not after 18 years of follow-up [1, 2, 37].

\section{ET}

In contrast to a large number of observational studies, the WHI trial demonstrated a significant risk reduction for breast cancer in ET versus placebo users [38]. The mean duration of ET was 7 years. Three smaller RCTs did not find significant differences in breast cancer risk of women using ET compared to placebo $[39,41]$. Observational studies have shown a small increase in breast cancer risk in women using ET. The duration of ET treatment leading to an elevated breast cancer risks is controversial. Breast cancer-specific mortality was reduced in ET uses in the 18-years follow-up in the WHI trial [37]. However, this calculation is based on a small number of breast cancer cases.

In summary, HRT may be associated with increased breast cancer risk. The elevation is relatively small and has to be included in the individual risk-benefit calculation before initiating HRT for climacteric symptoms.

\section{Vaginal ET and breast cancer risk}

Vaginal ET may lead to increases of systematic estrogen levels. It is not known whether it may also lead to increases of breast cancer risk. Ultra-low doses of vaginal ET (e.g. $0.03 \mathrm{mg}$ estriol, 2-3 applications per week) lead to good clinical effects on vaginal symptoms. It is unlikely that such an ultra-low-dose vaginal ET has a causal influence on breast cancer risk even when the therapy is used chronically [42].

\section{HRT after breast cancer}

Evidence-based statement

Level of Evidence $2 b$

Degree of consensus +++

HRT may increase the risk of relapse after breast cancer
Evidence-based recommendation

Level of Evidence 2a Grade of recommen- Degree of consendation $\mathrm{A}$ sus +++

HRT should not be used in women after breast cancer. In selected cases it may be used after ineffective non-hormonal treatments and severe limitations of quality of life

Meta-analyses including observational studies and RCTs could not demonstrate an increased risk of relapse of breast cancer after using HRT [43, 46]. However, these studies have considerable methodological limitations such as low numbers of cases and short follow-up. The HABITS trial, an RCT, demonstrated an increase of breast cancer relapse in breast cancer survivors using HRT [44, 45]. However, the number of only 442 women in this study was small. The Stockholm randomized trial with 378 breast cancer survivors found no increased risk of relapse in the HRT arm. Therefore, it is not possible to make reliable conclusions on the oncological safety of HRT among breast cancer survivors. In the randomised controlled LIBERATE trial 3000 women with vasomotoric symptoms after breast cancer were treated with tibolone or placebo. Tibolone led to increased risk of breast cancer (hazard ratio [HR] 1.40) after a median followup of 3.1 years [47].

\section{Vaginal ET after breast cancer}

Women who have been or are being treated for breast cancer may complain about vaginal symptoms such as dryness, dyspareunia, and pain. They use vaginal ET six times more often than systemic HRT. Vaginal ET may lead to increases in serum estrogen levels. Vaginal ETs are different in type, dosage, and frequency of application. In Germany, estriol is frequently used for vaginal ET. Ultra-low-dose estriol in combination with lactobacillus acidophilus was tested in a small study on its safety and efficacy. In this study, vaginal atrophy was significantly improved and serum levels of estriol were only increased during the initial period of ET. After 4 weeks of treatment, levels of estriol were slightly elevated in $50 \%$ of users while not at all in the remaining $50 \%$. It can be concluded that ultra-low-dose vaginal estriol therapy ( $0.03 \mathrm{mg}, 3$ applications per week) may be used in breast cancer survivors if non-hormonal alternatives had insufficient results [48]. 


\section{HRT and endometrial cancer}

\begin{tabular}{l}
\hline Evidence-based statement \\
\hline Level of Evidence $2 \quad$ Degree of consensus +++ \\
\hline HRT containing an estrogen without a progestin is a risk factor for \\
endometrial cancer in non-hysterectomized women. The effect is \\
dependent on the duration of treatment \\
\hline
\end{tabular}

Evidence-based statement

Level of Evidence $2 \quad$ Degree of consensus ++

Continuous combined HRT with conjugated equine estrogens and medroxyprogesterone acetate for an average duration of 5.6 years reduced the risk of endometrial cancer

\begin{tabular}{l}
\hline Evidence-based statement \\
\hline Level of Evidence 2 \\
\hline $\begin{array}{l}\text { Continuous combined HRT for less than } 5 \text { years does not increase } \\
\text { risk of endometrial cancer }\end{array}$ \\
\hline
\end{tabular}

\begin{tabular}{l}
\hline Evidence-based statement \\
\hline Level of Evidence $3 \quad$ Degree of consensus ++ \\
\hline $\begin{array}{l}\text { Long-term treatment with of continuous combined HRT for more } \\
\text { than } 6 \text { or } 10 \text { years may lead to an increased risk of endometrial } \\
\text { cancer }\end{array}$
\end{tabular}

\section{Evidence-based statement}

Level of Evidence 4

Degree of consensus +

The use of progesterone or dydrogesterone in continuous combined HRT may increase the risk of endometrial cancer

\section{Evidence-based statement}

Level of Evidence 3

Degree of consensus +++

Sequential combined HRT may increase the risk of endometrial cancer. The effect depends on duration, type and dose of progestin

Evidence-based statement

Level of Evidence 3 Grade of recommen- Degree of consendation A sus +++

Sequential combined HRT for a duration of less than 5 years including a synthetic progestin does not increase the risk of endometrial cancer risk
Evidence-based recommendation

Level of Evidence Grade of recommen- Degree of consen-

LLA dation A sus + +

ET should only be performed in hysterectomized women. A combined EPT in non-hysterectomized women should contain a progestin for a duration of 10 , better 14 days per treatment month

ET may lead to an increased risk of endometrial cancer in postmenopausal, non-hysterectomized women. This effect is dependent on duration and dose of ET [5]. Standard doses (e.g. $2 \mathrm{mg}$ estradiol, $0.625 \mathrm{mg}$ conjugated equine estrogen) increase the relative risk of endometrial cancer after more than 3 years of use up to five times and after 10 years of use up to ten times. This effect persists for several years after stopping ET. Therefore, HRT should include at least $1 \mathrm{mg}$ norethisterone or $2 \mathrm{mg}$ medroxyprogesterone acetate or an equivalent progestin in combined continuous HRT users or at least $5 \mathrm{mg}$ medroxyprogesterone acetate or an equivalent progestin in sequential HRT users with a sufficient duration of progestin treatment (10-15 days per treatment month) $[49,52]$. EPT is performed in a sequential or continuous combined form. Sequential EPT containing at least 10 days of progestin treatment (for up to 5 years) did not increase the risk of endometrial cancer [53]. Longer sequential EPT may increase endometrial cancer risk. The reduction of progestin use for less than 10 days per month significantly increases endometrial cancer risk (RR 3.0-4.4) [51, 54]. The progestin component of EPT was shown to influence the risk of endometrial cancer in the prospective $\mathrm{E} 3 \mathrm{~N}$ cohort study. In this study, long-term application of progesterone or dydrogesterone increased endometrial cancer risk (progesterone HR 2.66 after more than 5 years of treatment; dydrogesterone HR 1.69 after more than 5 years of treatment) [55]. Continuous combined EPT with conjugated equine estrogen and medroxyprogesterone acetate led to reduced risk for endometrial cancer [56]. In observational studies such as the Million Women Study and the EPIC study, a significantly reduced endometrial cancer risk was found in continuous combined HRT users [52, 53]. Other studies, however, documented significant risk increases [51, 54].

\section{Vaginal ET and endometrial cancer risk}

Clinical studies did not show increased rates of endometrial hyperplasia after vaginal ET. Therefore, it is not recommended to add a progestin to vaginal ET. However, there are no data on endometrial safety of vaginal ET when used for more than 1 year [5]. 


\section{HRT after endometrial cancer}

\begin{tabular}{l}
\hline $\begin{array}{l}\text { Evidence-based statement } \\
\text { Level of Evidence } 2 \mathrm{~b}\end{array}$ \\
$\begin{array}{l}\text { The effect of HRT on the risk of relapse after treatment of endome- } \\
\text { trial cancer has not been investigated sufficiently }\end{array}$ \\
\hline $\begin{array}{l}\text { Evidence-based recommendation } \\
\text { Level of Evidence } 2 \mathrm{~b} \text { Grade of recommen- } \\
\text { dation EK }\end{array}$ \\
$\begin{array}{l}\text { In patients who have been treated for endometrial cancer, HRT may } \\
\text { se used for the treatment of climacteric symptoms if they have } \\
\text { severe quality of life limitations and in whom non-hormonal treat- } \\
\text { ments were not effective }\end{array}$ \\
\hline
\end{tabular}

A recent meta-analysis has included only one randomized trial and five observational studies assessing the safety of HRT in women who have been treated for endometrial cancer. Of note, the risk of endometrial cancer relapse was reduced in HRT users. However, most studies included in this meta-analysis were retrospective observational studies. Therefore, the evidence regarding the oncological safety of HRT among endometrial cancer survivors is limited. It can only be concluded that HRT after early stage endometrial cancer may not lead to a relevant increase of the risk of relapse [5, 57, 59].

\section{Vaginal ET after endometrial cancer}

\begin{tabular}{l}
\hline \begin{tabular}{l} 
Evidence-based recommendation \\
\hline $\begin{array}{l}\text { Level of Evidence } 4 \\
\text { Grade of recommen- } \\
\text { dation A }\end{array}$
\end{tabular} $\begin{array}{l}\text { Degree of consen- } \\
\text { sus }++\end{array}$ \\
$\begin{array}{l}\text { Patients with symptoms of vaginal atrophy after treatment of } \\
\text { endometrial cancer should be treated primarily with moisturizers } \\
\text { or lubricants }\end{array}$ \\
\hline Consensus-based recommendation \\
\hline $\begin{array}{l}\text { EK } \\
\text { After treatment of endometrial cancer, vaginal ET may be used if } \\
\text { lubricants or cremes have proven to be ineffective }\end{array}$ \\
\hline
\end{tabular}

Patients who have been treated for endometrial cancer may complain vaginal dryness, pain, dyspareunia, vaginal bleeding, and urinary incontinence. This may lead to sexual dysfunction and reduction of quality of life. Since it cannot be excluded that vaginal ET may lead to increase the risk of relapse, endometrial cancer survivors should be treated with non-hormonal moisturizers or lubricants [60]. Ph-stabilizing preparations with a $\mathrm{pH}$ between 4 and 4.5 have been shown to be efficient in this indication [61]. Local ET may alleviate the symptoms of vaginal atrophy after radiotherapy of the vagina [62]. Retrospective observational studies did not show increased rates of relapse after vaginal ET [63]. However, the evidence is limited and does not prove oncological safety [5].

\section{HRT and ovarian cancer risk}

\begin{tabular}{l}
\hline \begin{tabular}{l} 
Evidence-based recommendation \\
\hline Level of Evidence 2a $\begin{array}{l}\text { Grade of recommen- } \\
\text { dation A }\end{array}$ \\
$\begin{array}{l}\text { Degree of consen- } \\
\text { sus }++\end{array}$ \\
may increase ovarian cancer risk. This effect has been observed \\
after treatment durations of less than 5 years and is reduced after \\
stopping treatment
\end{tabular} \\
\hline
\end{tabular}

The Collaborative Group on Epidemiological Studies of Ovarian Cancer performed a meta-analysis of 52 studies. This included data from 21488 postmenopausal women with ovarian cancer. Data from prospective trials showed that HRT users had increased risk for ovarian cancer after HRT durations of less than 5 years (RR 1.43). The absolute increase of risk is 1 in 1000 after 5 years and 1 in 1600 women using HRT [64].

\section{HRT after ovarian cancer}

\begin{tabular}{|c|c|c|}
\hline \multicolumn{3}{|c|}{ Evidence-based statement } \\
\hline Level of Evidence $2 b$ & & Degree of consensus ++ \\
\hline \multicolumn{3}{|c|}{ The safety of HRT after treatment of ovarian cancer is unclear } \\
\hline \multicolumn{3}{|c|}{ Evidence-based recommendation } \\
\hline Level of Evidence $2 b$ & $\begin{array}{l}\text { Grade of recommen- } \\
\text { dation } 0\end{array}$ & $\begin{array}{l}\text { Degree of consen- } \\
\text { sus }+++\end{array}$ \\
\hline
\end{tabular}

After treatment, ovarian cancer patients may experience natural or therapy-induced menopause. These patients may suffer from climacteric symptoms. Younger women may develop estrogen-associated diseases such as coronary heart disease and osteoporosis $[65,70]$. There are only 
few studies that examined the safety of HRT after ovarian cancer [71]. Three observational studies could not demonstrate increased risk of relapse [66, 68, 69]. However, there are a number of methodological limitations. A randomized study with 150 patients showed improved survival in the group of women treated with HRT after a median follow-up of 19.1 years (HR 0.63; 95\% CI 0.44-0.90). The authors conclude that HRT after ovarian cancer is safe. However, this study has a number of limitations and the safety of HRT after ovarian cancer remains unclear [67]. Since none of the studies showed an increased, but rather a risk reduction, HRT may be considered when women complain of severe climacteric symptoms. Especially in younger women with iatrogenic menopause after ovarian cancer treatment, the risk of mortality due to coronary heart disease is increased. In these women ET should be considered.

\section{HRT and risk for colorectal cancer}

\begin{tabular}{ll}
\hline $\begin{array}{l}\text { Evidence-based recommendation } \\
\text { Level of Evidence 2a }\end{array}$ & $\begin{array}{l}\text { Grade of recommen- } \\
\text { dation A }\end{array}$ \\
\hline $\begin{array}{l}\text { Women should be informed that HRT may reduce the risk of } \\
\text { sus }+++\end{array}$ \\
$\begin{array}{l}\text { colorectal cancer. HRT should not be used for colorectal cancer } \\
\text { prevention }\end{array}$ \\
\hline
\end{tabular}

Reproductive factors may influence the risk of colorectal cancer. Studies have shown that HRT has no effect or reduces the risk for colorectal cancer [72, 73]. In the WHI trial, the risk of colon cancer was reduced by $37 \%$ in EPT users. ET did not have any effect on colorectal cancer risk [74]. Observational studies had conflicting results. The majority of these studies showed a risk reduction after HRT use. A meta-analysis including data from RCTs and observational studies showed that EPT as well as ET significantly reduced the risk of colorectal cancer (RR $0.74 ; 95 \%$ CI $0.68-0.81$ and RR 0.79 ; 95\% CI 0.69-0.91, respectively). A recent publication of data from five Danish cancer registries including 1.1 million women also demonstrated that ET and EPT reduced the risk of colorectal cancer with a minimal effect of EPT on rectal cancer [73].
Premature ovarian insufficiency (POI)

\begin{tabular}{l}
\hline \begin{tabular}{ll}
\hline Evidence-based recommendation \\
\hline Level of Evidence 2b Grade of recommen- \\
dation B
\end{tabular} \\
$\begin{array}{l}\text { Degree of consen- } \\
\text { sus }++\end{array}$ \\
$\begin{array}{l}\text { Homen with POI should be informed about the importance of } \\
\text { natural menopause if there are no contraindications against HRT } \\
\text { or combined oral contraceptives }\end{array}$ \\
\hline
\end{tabular}

Evidence-based statement

$\overline{\text { Level of Evidence } 2 b \quad \text { Degree of consensus }++}$

There is no evidence for different treatment efficacy of HRT and combined oral contraceptives in women with POI

Premature ovarian insufficiency (POI) or premature ovarian failure (POF) is defined as loss of ovarian function before the age of 40 and affects $1 \%$ of women [75]. Etiology is heterogenous and comprises genetic, autoimmune, iatrogenic, and unknown causes. A careful evaluation of the medical history including medical treatments, previous surgery or hereditary disorders is recommended. Laboratory findings are an elevated $\mathrm{FSH}>30 \mathrm{mIU} / \mathrm{ml}$, determined twice with 4-6 weeks in between. AMH is of no benefit for the final diagnosis $[1,2]$.

All types of menstrual disturbances and various climacteric symptoms can be found. Women with POI/POF have a higher risk for estrogen-dependent diseases. However, there is no prospective study which shows lower mortality by hormonal substitution. It might make sense to continue hormonal treatment in women with POF until the average age of menopause.

There seems to be no difference between a hormonal substitution with HRT or contraceptive pills, although two studies reported a small difference in blood pressure in favour of HRT compared to contraceptive pills $[76,77]$. Both treatment options can be discussed with POI/POF patients. In women $>40$ years, HRT should be preferred.

Women with POI/POF should be informed about the following facts:

- HRT might have a positive effect on blood pressure compared to contraceptive pills.

- HRT and contraceptive pills have a positive effect on bone health.

- HRT does not offer protection from pregnancies.

- Women with POI and contraindications for HRT should be advised about cardiovascular risks, bone health and alternative treatments of climacteric symptoms.

- Women with POI should be generously transferred to specialized centres. 
Table 1 Estimated event rate difference associated with EPT or ET vs. placebo in postmenopausal women

\begin{tabular}{lll}
\hline Events & \multicolumn{2}{l}{$\begin{array}{l}\text { Difference of events per } 10,000 \text { women } \\
\text { years }(95 \% \mathrm{CI})^{\mathrm{a}}\end{array}$} \\
\cline { 2 - 3 } & EPT oral & ET oral $^{\mathrm{b}}$ \\
\hline Breast cancer & $9(1$ bis 19$)$ & $-7(-14$ bis 0.4$)$ \\
Coronary heart disease & $8(0$ bis 18$)$ & $-3(-12 \text { bis } 8)^{\mathrm{c}}$ \\
Stroke & $9(2$ bis 19$)$ & $11(2 \text { bis } 23)^{\mathrm{c}}$ \\
Thromboembolism & $21(12$ bis 33$)$ & $11(3 \text { bis } 22)^{\mathrm{c}}$ \\
Dementia & $22(4$ bis 53$)$ & $12(-4$ bis 41$)$ \\
Gallbladder disease & $21(10$ bis 34$)$ & $30(16$ bis 48$)$ \\
Urinary incontinence & $876(606$ bis 1168$)$ & $1261(880$ bis 1689$)$ \\
Bowel cancer & $-6(-9$ bis -1$)$ & $2(-3$ bis 10$)$ \\
Ovarian cancer & $2(-1$ bis 6$)$ & No data \\
Lung cancer & $1(-4$ bis 7$)$ & $1(-4$ bis 8$)$ \\
Fractures (osteoporosis $)$ & $-44(-71$ bis -13$)$ & $-53(-69$ bis -39$)$ \\
Diabetes & $-14(-24$ bis -3$)$ & $-19(-34$ bis -3$)$ \\
Mortality & $1(-9$ bis 12$)$ & $1(-10$ bis 14$)$ \\
\hline
\end{tabular}

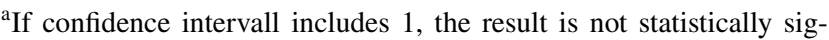
nificant

${ }^{\mathrm{b}}$ Estrogen alone only in hysterectomised women

${ }^{c}$ For transdermal ET in doses from up to $50 \mu \mathrm{g} /$ day observational studies did not demonstrate an influence of the risk for coronary heart disease, stroke or thromboembolism (modified table 3, Gartlehner et al. JAMA 2017)

\section{Informing women about HRT}

Women should be informed about risks and benefits of medical interventions. The communication should include the probabilities of expected benefits and possible risks of harm with the patient and possibly with an accompanying person. For an individual assessment and evaluation of the probability of benefit and the risk of harm of HRT individual factors such as the woman's general state of health, age at menopause, previous HRT, duration and use, doses and type of HRT and diseases while using HRT should be taken into consideration. To give adequate information about the risks to the woman seeking advice, the doctor must be familiar with the principles of risk calculation. He or she should also be able to communicate the probabilities in such a way that the patient can make her own individual decision for or against the initiation of HT. The figures necessary for this communication can be found in the long version and in Table 1 [1].

Acknowledgement Open Access funding provided by Projekt DEAL.

Author contributions OO: manuscript writing and editing. MJB: manuscript writing and editing. ECI: manuscript writing and editing. TS: manuscript writing and editing. EW: manuscript writing and editing. CT: manuscript writing and editing.
Funding No funding was received.

\section{Compliance with ethical standards}

Conflict of interest Author O. Ortmann declares that he has no conflict of interest. Author M. J. Beckermann declares that she has no conflict of interest. Author E. C. Inwald declares that she has no conflict of interest. Author T. Strowitzki declares that he has no conflict of interest. Author E. Windler declares that he has no conflict of interest. Author C. Tempfer declares that he has no conflict of interest.

Human/animal rights This article does not contain any studies with human participants or animals performed by any of the authors.

Open Access This article is licensed under a Creative Commons Attribution 4.0 International License, which permits use, sharing, adaptation, distribution and reproduction in any medium or format, as long as you give appropriate credit to the original author(s) and the source, provide a link to the Creative Commons licence, and indicate if changes were made. The images or other third party material in this article are included in the article's Creative Commons licence, unless indicated otherwise in a credit line to the material. If material is not included in the article's Creative Commons licence and your intended use is not permitted by statutory regulation or exceeds the permitted use, you will need to obtain permission directly from the copyright holder. To view a copy of this licence, visit http://creativecommons.org/licenses/by/4.0/.

\section{Appendix}

Detailed information on the development and methodology of the guideline following the criteria of the AWMF can be found on the AWMF homepage (see [1]).

\section{Guideline group}

Coordinating guideline author in charge.

\begin{tabular}{ll}
\hline Author & $\begin{array}{l}\text { Association of Scientific Medical Societies } \\
(\text { AWMF) }\end{array}$ \\
\hline Prof. Dr. Olaf Ortmann & $\begin{array}{l}\text { Deutsche Gesellschaft für Gynäkologie und } \\
\text { Geburtshilfe (DGGG) } \\
\text { German Society of Gynecology }\end{array}$ \\
\hline
\end{tabular}

\section{Guideline group}

DGGG-Working Group

AWMF/Non-AWMF-Scientific Society, Organisation

Arbeitsgemeinschaft Gynäkologische Onkologie (AGO)

Arbeitsgemeinschaft für Urogynäkologie und plastische Beckenbodenrekonstruktion (AGUB)

Berufsverband der Frauenärzte (BVF) 
DGGG-Working Group

AWMF/Non-AWMF-Scientific Society, Organisation

D.A.CH-Gesellschaft Herz-Kreislauf-Prävention

Deutsche Gesellschaft für Allgemeinmedizin und Familienmedizin (DEGAM)

Deutsche Gesellschaft für Angiologie, Gesellschaft für Gefäßmedizin (DGA)

Deutsche Gesellschaft für Endokrinologie (DGE)

Deutsche Gesellschaft für Gynäkologische Endokrinologie und Fortpflanzungsmedizin (DGGEF)

Deutsche Gesellschaft für Gynäkologie und Geburtshilfe (DGGG)

Deutsche Gesellschaft für Hämatologie und Medizinische Onkologie (DGHO)

Deutsche Gesellschaft für Innere Medizin (DGIM)

Deutsche Gesellschaft für Kardiologie - Herz- und Kreislauf-

forschung (DGK)

Deutsche Gesellschaft für Neurologie (DGN)

Deutsche Gesellschaft für Pharmakologie (DGP)

Deutsche Gesellschaft für psychosomatische Frauenheilkunde und Geburtshilfe (DGPFG)

Deutsche Gesellschaft für Psychiatrie und Psychotherapie, Psychosomatik und Nervenheilkunde (DGPPN)

Deutsche Gesellschaft für Senologie (DGS)

Deutsche Krebsgesellschaft (DKG)

Deutsche Menopause Gesellschaft (DMG)

Dachverband Osteologie (DVO)

European Menopause and Andropause Society (EMAS)

Frauenselbsthilfe nach Krebs

Gesellschaft für Phytotherapie (GPT)

International Menopause Society (IMS)

Österreichische Gesellschaft für Gynäkologie und Geburtshilfe (OEGGG)

Schweizerische Gesellschaft für Gynäkologie und Geburtshilfe (SGGG)

\begin{tabular}{ll}
\hline $\begin{array}{l}\text { Author } \\
\text { Delegate }\end{array}$ & $\begin{array}{l}\text { DGGG-Working Group } \\
\text { AWMF/Non-AWMF-Scientific } \\
\text { Society, Organisation }\end{array}$ \\
\hline Dr. med. C. Albring & $\begin{array}{l}\text { BVF, member of the steering } \\
\text { committee } \\
\text { DEGAM }\end{array}$ \\
Prof. Dr. E. Baum & DGPFG \\
Dr. med. M. Beckermann & D.A.CH \\
Prof. Dr. K. Bühling & DGGG \\
Prof. Dr. G. Emons & DGP \\
Prof. Dr. T. Gudermann & DVO \\
Prof. Dr. P. Hadji & SGGG \\
Prof. Dr. B. Imthurn & 2nd guideline coordinator \\
PD Dr. med. E.C. Inwald & DMG, member of the steering \\
Prof. Dr. L. Kiesel & committee \\
Prof. Dr. D. Klemperer & Expert, patient information \\
Dr. P. Klose & GPT \\
Dr. med. K. König & BVF \\
Prof. Dr. S. Krüger & DGPPN \\
Prof. Dr. J. Langhorst & GPT \\
\hline
\end{tabular}

\begin{tabular}{ll}
\hline Author & DGGG-Working Group \\
Delegate & AWMF/Non-AWMF-Scientific \\
& Society, Organisation \\
\hline Prof. Dr. M. Leitzmann & Expert, Epidemiology \\
Prof. Dr. A. Ludolph & DGN \\
Prof. Dr. D. Lüftner & DGHO \\
Frau D. Müller & Frauenselbsthilfe nach Krebs \\
Prof. Dr. J. Neulen & DGGEF \\
Dr. med. M. Nothacker & AWMF \\
Prof. Dr. O. Ortmann & Guideline coordinator, principle \\
& author of the guideline, member \\
& of the steering committee \\
Prof. Dr. E. Petri (deceased & AGUB \\
21.09.2019) & \\
Dr. med. H. Prautzsch & DEGAM \\
Prof. Dr. F. Regitz-Zagrosek & DGK \\
Dr. med. K. Schaudig & Expert, Gynecologic Endocrinol- \\
& ogy \\
Prof. Dr. F. Schütz & DGS \\
Dr. med. A. Schwenkhagen & Expert, Gynecologic Endocrinol- \\
& ogy \\
Prof. Dr. T. Strowitzki & DGE \\
Prof. Dr. P. Stute & EMAS, member of the steering \\
& committee \\
Prof. Dr. B.-M. Taute & DGA \\
Prof. Dr. C. Tempfer & AGO \\
Prof. Dr. C. von Arnim & DGN \\
Prof. Dr. L. Wildt & OEGGG \\
Prof. Dr. E. Windler & DGIM, member of the steering \\
& committee \\
\hline & \\
& \\
&
\end{tabular}

\section{Statements and recommendations}

Grade of recommendation:

A strong recommendation.

B recommendation with moderate obligation.

0 open recommendation with low obligation.

Degree of consensus:

$+++\quad$ strong consensus ( $>95 \%$ of delegates agree).

++ consensus ( $>75$ to $95 \%$ of delegates agree).

$+\quad$ majority agrees ( $>50$ to $75 \%$ of delegates agree).

- $\quad$ no consensus ( $<51 \%$ of delegates agree).

LLA Leitlinienadaptation, guideline adaptation.

*Dissenting opinion of the German Society for Phytotherapy (GPT):

The GPT does not support the undifferentiated recommendation on the use of cimicifuga, the level of evidence and grade of recommendation. In contrast to other 
cimicifuga products (e.g. food supplements), cimicifuga medical products with marketing authorizations have proven their usefulness. Only these should be recommended.

Grade of recommendation:

A (isopropanolic Cimicifuga medicinal products). B (ethanolic Cimicifuga medicinal products)

\section{Level of evidence:}

$1 \mathrm{~b}$ (isopropanolic Cimicifuga medicinal products). $2 \mathrm{~b}$ (ethanolic Cimicifuga medicinal products)

For the full text on the position of the GPT see electronic supplementary material.

\section{References}

1. S3 Level, AWMF Registry No. 015-062 (2020) Peri- and postmenopause-diagnosis and interventions. Guideline of the DGGG, SGGG and OEGGG. https://www.awmf.org/leitlinien/detail/ 11/015-062.html

2. National Institute for Health and Care Excellence (NICE) Guideline (2015) Menopause Full Guideline, Methods, evidence and recommendations, Version 1.5. https://www.nice.org.uk/guidance/ ng23/evidence/full-guideline-pdf-559549261

3. Nelson HD, Haney E, Humphrey L, Miller J, Nedrow A, Nicolaidis C, Vesco K, Walker M, Bougatsos C, Nygren P (2005) Management of menopause-related symptoms. Evid Rep Technol Assess 120:p12

4. Avis NE, Crawford SL, Greendale G, Bromberger JT, Everson-Rose SA, Old EB, Hess R, Joffe H, Kravitz HM, Tepper PG, Thurston RC (2015) Duration of menopausal vasomotor symptoms over the menopause transition. JAMA Intern Med. 175(4):531-539

5. AWMF Registernummer: 032/034-OL (2018) Diagnostik, Therapie und Nachsorge der Patientinnen mit Endometriumkarzinom, Langversion 1.0. http://www.leitlinienprogramm-onkologie.de/ leitlinien/endometriumkarzinom/

6. Cody JD, Jacobs ML, Richardson K, Moehrer B, Hextall A. Oestrogen therapy for urinary incontinence in post-menopausal women. Cochrane Database Syst Rev 2012

7. AWMF Registernummer: 015/005 (2015) Interdisziplinäre S2eLeitlinie für die Diagnostik und Therapie der Belastungsinkontinenz der Frau, Langversion 2015. https://www.awmf.org/uploa ds/tx_szleitlinien/015_0051_S2e_Belastungsinkontinenz_201307.pdf

8. Rahn DD, Carberry C, Sanses TV, Mamik MM et al (2014) Vaginal estrogen for genitourinary syndrome of menopause-a systematic review. Obstet Gynecol 124(6):1147-1156

9. Andersson KE, Chapple CR, Cardozo L, Cruz F, Gratzke C, Lee KS, Tannenbaum C, Wein AL (2013) Pharmacological treatment of urinary incontinence. In: Incontinence-5th int consult on incont ICUD-EAU, pp 625-728

10. Lucas MG, Bosch RJL, Burkhard FC, Cruz F, Madden TB, Nambiar AK, Neisius A, de Ridder DJMK, Tubaro A, Turner WH, Pickard RS (2012) EAU guidelines on assessment and nonsurgical management of urinary incontinence. Eur Urol 62:1130-1142

11. Clinical guideline (2013) Urinary incontinence in women: management. nice.org.uk/guidance/cg171
12. Lüthje P, Hirschberg AL, Brauner A (2014) Estrogenic action on innate defense mechanisms in the urinary tract. Maturitas 77(1):32-36

13. Wang C, Symington JW, Ma E, Cao B, Mysorekar IU (2013) Estrogenic modulation of uropathogenic Escherichia coli in fection pathogenesis in a murine menopause model. Infect Immunity 81(3):733-739

14. AWMF Registernummer: 043/044 (2017) Leitlinienprogramm DGU: Interdisziplinare S3 Leitlinie: Epidemiologie, Diagnostik, Therapie, Pravention und Management unkomplizierter, bakterieller, ambulant erworbener Harnwegsinfektionen bei erwachsenen Patienten. Langversion 1.1-2. http://www.awmf.org/uploads/ tx_szleitlinien/043-0441_S3_Harnwegsinfektionen

15. Beerepoot MA, Geerlings SE, van Haarst EP, van Charante NM, ter Riet G (2013) Nonantibiotic prophylaxis for recurrent urinary tract infections: a systematic review and meta-analysis of randomized controlled studies. J Urol 190:1981-1989

16. Perrotta C, Aznar M, Mejia R, Albert X, Ng CW (2008) Oestrogens for preventing recurrent urinary tract infection in postmenopausal women. Cochrane Database Syst Rev (2):CD005131

17. Manson JE, Hsia J, Johnson KC, Rossouw JE, Assaf AR, Lasser NL, Trevisan M, Black HR, Heckbert SR, Detrano R, Strickland OL, Wong ND, Crouse JR, Stein E, Cushman M, Women's Health Initiative Investigators (2003) Estrogen plus progestin and the risk of coronary heart disease. N Engl J Med 349:523-534

18. Harman SM, Black DM, Naftolin F, Brinton EA, Budoff MJ, Cedars MI, Hopkins PN, Lobo RA, Manson JE, Merriam GR, Miller VM, Neal-Perry G, Santoro N, Taylor HS, Vittinghoff E, Yan M, Hodis HN (2014) Arterial imaging outcomes and cardiovascular risk factors in recently menopausal women: a randomized trial. Ann Intern Med 161:249-260

19. Canonico M, Oger E, Plu-Bureau G, Conard J, Meyer G, Lévesque H, Trillot N, Barrellier MT, Wahl D, Emmerich J, Scarabin PY, Estrogen, and Thromboembolism Risk (ESTHER) Study Group (2007) Hormone therapy and venous thromboembolism among postmenopausal women: impact of the route of estrogen administration and progestogens: the ESTHER study. Circulation 115:840-845

20. Canonico M, Fournier A, Carcaillon L, Olié V, Plu-Bureau G, Oger E, Mesrine S, Boutron-Ruault MC, Clavel-Chapelon F, Scarabin PY (2010) Postmenopausal hormone therapy and risk of idiopathic venous thromboembolism: results from the E3N cohort study. Arterioscler Thromb Vasc Biol 30:340-345

21. Sweetland S, Beral V, Balkwill A, Liu B, Benson VS, Canonico M, Green J, Reeves GK, Million Women Study Collaborators (2012) Venous thromboembolism risk in relation to use of different types of postmenopausal hormone therapy in a large prospective study. J Thromb Haemost. 10:2277-2286

22. Manson JE, Chlebowski RT, Stefanick ML, Aragaki AK, Rossouw JE, Prentice RL, Anderson G, Howard BV, Thomson CA, LaCroix AZ, Wactawski-Wende J, Jackson RD, Limacher M, Margolis KL, Wassertheil-Smoller S, Beresford SA, Cauley JA, Eaton CB, Gass M, Hsia J, Johnson KC, Kooperberg C, Kuller LH, Lewis CE, Liu S, Martin LW, Ockene JK, O'Sullivan MJ, Powell LH, Simon MS, Van Horn L, Vitolins MZ, Wallace RB (2013) Menopausal hormone therapy and health outcomes during the intervention and extended poststopping phases of the Women's Health Initiative randomized trials. JAMA 310:1353-1368

23. Hulley S, Grady D, Bush T, Furberg C, Herrington D, Riggs B, Vittinghoff E (1998) Randomized trial of estrogen plus progestin for secondary prevention of coronary heart disease in postmenopausal women. Heart and Estrogen/progestin Replacement Study (HERS) Research Group. JAMA 280:605-613

24. Sare GM, Gray LJ, Bath PM (2008) Association between hormone replacement therapy and subsequent arterial and venous vascular events: a meta-analysis. Eur Heart J 29:2031-2041 
25. Boardman HM, Hartley L, Eisinga A, Main C, Roqué i Figuls M, Bonfill Cosp X, Gabriel-Sanchez R, Knight B (2015) Hormone therapy for preventing cardiovascular disease in postmenopausal women. Cochrane Database Syst Rev. https://doi. org/10.1002/14651858.cd002229.pub4

26. Mohammed K, Abu Dabrh AM, Benkhadra K, Al Nofal A, Carranza Leon BG, Prokop LJ, Montori VM, Faubion SS, Murad MH (2015) Oral vs transdermal estrogen therapy and vascular events: a systematic review and meta-analysis. J Clin Endocrinol Metab 100:4012-4020

27. Bath PM, Gray LJ (2005) Association between hormone replacement therapy and subsequent stroke: a meta-analysis. BMJ 330:3 42

28. Gu H, Zhao X, Zhao X, Yang Y, Lv X (2014) Risk of stroke in healthy postmenopausalwomen during and after hormone therapy: a meta-analysis. Menopause 21:1204-1210

29. Wells G, Tugwell P, Shea B, Guyatt G, Peterson J, Zytaruk N et al (2002) Meta-analyses of therapies for postmenopausal osteoporosis. V. Meta-analysis of the efficacy of hormone replacement therapy in treating and preventing osteoporosis in postmenopausal women. Endocr Rev 23(4):529-539

30. Torgerson DJ, Bell-Syer SE (2001) Hormone replacement therapy and prevention of nonvertebral fractures: a meta-analysis of randomized trials. JAMA 285(22):2891-2897

31. Yu X, Zhou S, Wang J, Zhang Q, Hou J, Zhu L, He Y, Zhao J, Zhong S (2017) Hormone replacement therapy and breast cancer survival: a systematic review and meta-analysis of observational studies. Breast Cancer 24(5):643-657. https://doi.org/10.1007/ s12282-017-0789-5 (epub 2017 Jun 10)

32. AWMF-Register-Nr.: 183/001 (2017) Prophylaxe, Diagnostik und Therapie der OSTEOPOROSE bei postmenopausalen Frauen und Männern. Leitlinie des Dachverbands der Deutschsprachigen Wissenschaftlichen Osteologischen Gesellschaften e.V.

33. (2015) DGPPN, BÄK, KBV, AWMF (Hrsg.) für die Leitliniengruppe Unipolare Depression*. S3-Leitlinie/Nationale VersorgungsLeitlinie Unipolare Depression-Langfassung, 2. Auflage. Version 5. https://doi.org/10.6101/AZQ/000364. www. depression.versorgungsleitlinien.de

34. Colvin A, Richardson GA, Cyranowski JM, Youk A, Bromberger JT (2017) The role of family history of depression and the menopausal transition in the development of major depression in midlife women: study of women's health across the nation mental health study (SWAN MHS). Depress Anxiety 34(9):826-835

35. Prentice RL, Manson JE, Langer RD, Anderson GL, Pettinger M, Jackson RD, Johnson KC, Kuller LH, Lane DS, Wactawski-Wende J, Brzyski R, Allison M, Ockene J, Sarto G, Rossouw JE (2009) Benefits and risks of postmenopausal hormone therapy when it is initiated soon after menopause. Am J Epidemiol 170:12-23

36. Cordina-Duverger E, Truong T, Anger A, Sanchez M, Arveux P, Kerbrat P, Guénel P (2013) Risk of breast cancer by type of menopausal hormone therapy: a case-control study among postmenopausal women in France. PLoS ONE 8(11):e78016

37. Manson JE, Aragaki AK, Rossouw JE et al (2017) Menopausal hormone therapy and long-term all-cause and cause-specific mortality the Women's Health Initiative randomized trials. JAMA 318(10):927-938. https://doi.org/10.1001/jama.2017.11217

38. Anderson GL, Limacher M, Assaf AR, Bassford T, Beresford SA, Black H, Bonds D, Brunner RL, Brzyski RG, Caan BJ (2004) Effects of conjugated equine estrogen in postmenopausal women with a hysterectomy. JAMA 291:1701-1712

39. Hodis HN, Mack WJ, Lobo RA, Shoupe D, Sevanian A, Mahrer PR, Selzer RH, Liu CR, Liu CH, Azen SP (2001) Estrogen in the prevention of atherosclerosis: a randomized, double-blind, placebo-controlled trial. Ann Intern Med 135:939-953
40. Viscoli CM, Brass LM, Kernan WN, Sarrel PM, Suissa S, Horwitz RI (2001) A clinical trial of estrogen-replacement therapy after ischemic stroke. N Engl J Med 345:1243-1249

41. Cherry N, Gilmour K, Hannaford P, Heagarty A, Khan MA, Kitchener HC, McNamee R, Elstein M, Kay C, Seif M (2002) Oestrogen therapy for prevention of reinfarction in postmenopausal women: a randomised placebo controlled trial. Lancet 360:2001-2008

42. Moegele M, Buchholz S, Seitz S, Ortmann O (2012) Vaginal estrogen therapy in postmenopausal breast cancer patients treated with aromatase inhibitors. Arch Gynecol Obstet. 285(5):13971402. https://doi.org/10.1007/s00404-011-2181-6

43. Holmberg L, Anderson H (2004) HABITS (hormonal replacement therapy after breast cancer-is it safe?), a randomised comparison: trial stopped. Lancet 363(9407):453-455

44. Holmberg L, Iversen OE, Rudenstam CM, Hammar M, Kumpulainen E, Jaskiewicz J, Jassem J, Dobaczewska D, Fjosne HE, Peralta O, Arriagada R, Holmqvist M, Maenpaa J, HABITS Study Group (2008) Increased risk of recurrence after hormone replacement therapy in breast cancer survivors. J Natl Cancer Inst 100(7):475-482 (Erratum in: J Natl Cancer Inst. 2008;100:685)

45. Farquhar CM, Marjoribanks J, Lethaby A, Lamberts Q, Suckling JA, the Cochrane HT Study Group (2005) Long-term hormone therapy for perimenopausal and postmenopausal women. Cochrane Database Syst Rev (3):CD004143 (Review. Update in: Cochrane Database Syst Rev. 2009;(2):CD004143)

46. Collins JA, Blake JM, Crosignani PG (2005) Breast cancer risk with postmenopausal hormonal treatment. Hum Reprod Update 11:545-560

47. Kenemans P, Bundred NJ, Foidart JM, Kubista E, von Schoultz B, Sismondi P, Vassilopoulou-Sellin R, Yip CH, Egberts J, Mol-Arts M, Mulder R, van Os S, Beckmann MW (2009) Safety and efficacy of tibolone in breast-cancer patients with vasomotor symptoms: a double-blind, randomised, non-inferiority trial. Lancet Oncol 10:135-146

48. Donders G et al (2014) Ultra-low-dose estriol and Lactobacillus acidophilus vaginal tablets (Gynoflor ${ }^{\circledR}$ ) for vaginal atrophy in postmenopausal breast cancer patients on aromatase inhibitors: pharmacokinetic, safety, and efficacy phase I clinical study. Breast Cancer Res Treat 145(2):371-379

49. Grady D, Gebretsadik T, Kerlikowske K, Ernster V, Petitti D (1995) Hormone replacement therapy and endometrial cancer risk: a meta-analysis. Obstet Gynecol 85(2):304-313

50. Nelson HD, Humphrey LL, Nygren P, Teutsch SM, Allan JD (2002) Postmenopausal hormone replacement therapy: scientific review. JAMA 288:872-881

51. Lacey JV Jr, Brinton LA, Lubin JH, Sherman ME, Schatzkin A, Schairer C (2005) Endometrial carcinoma risks among menopausal estrogen plus progestin and unopposed estrogen users in a cohort of postmenopausal women. Cancer Epidemiol Biomark Prev 14(7):1724-1731

52. Allen NE, Tsilidis KK, Key TJ, Dossus L, Kaaks R, Lund E, Bakken K, Gavrilyuk O, Overvad K, Tjonneland A, Olsen A, Fournier A, Fabre A, Clavel-Chapelon F, Chabbert- Buffet N, Sacerdote C, Krogh V, Bendinelli B, Tumino R, Panico S, Bergmann M, Schuetze M, van Duijnhoven FJB, Bueno-de-Mesquita H, OnlandMoret NC, van Gils CH, Amiano P, Barricarte A, Chirlaque MD, Molina-Montes ME, Redondo ML, Duell EJ, Khaw KT, Wareham N, Rinaldi S, Fedirko V, Mouw T, Michaud DS, Riboli E (2010) Menopausal hormone therapy and risk of endometrial carcinoma among postmenopausal women in the European Prospective Investigation into cancer and nutrition. Am J Epidemiol 172:1394-1403 
53. Beral V, Bull D, Reeves G, Million Women Study Collaborators (2005) Endometrial cancer and hormone-replacement therapy in the Million Women Study. Lancet 365(9470):1543-1551

54. Razavi P, Pike MC, Horn-Ross PL, Templeman C, Bernstein L, Ursin G (2010) Long-term postmenopausal hormone therapy and endometrial cancer. Cancer Epidemiol Biomark Prev 19(2):475-483

55. Fournier A, Dossus L, Mesrine S, Vilier A, Boutron-Ruault MC, Clavel-Chapelon F, Chabbert-Buffet N (2014) Risks of endometrial cancer associated with different hormone replacement therapies in the E3N cohort, 1992-2008. Am J Epidemiol 180(5):508-517

56. Chlebowski R et al (2015) Aromatase inhibitors, tamoxifen, and endometrial cancer in breast cancer survivors. Cancer 121:2147-2155

57. Shim SH, Lee SJ, Kim SN (2014) Effects of hormone replacement therapy on the rate of recurrence in endometrial cancer survivors: a meta-analysis. Eur J Cancer 50(9):1628-1637

58. Manley K, Edey K, Braybrooke J, Murdoch J (2012) Hormone replacement therapy after endometrial cancer. Menopause Int 18(4):134-138

59. Felix AS, Arem H, Trabert B, Gierach GL, Park Y, Pfeiffer RM, Brinton LA (2015) Menopausal hormone therapy and mortality among endometrial cancer patients in the NIH-AART Diet and Health Study. Cancer Causes Control 26:1055-1063

60. Lester J, Pahouja G, Andersen B, Lustberg M (2015) Atrophic vaginitis in breast cancer survivors: a difficult survivorship issue. J Pers Med 5(2):50-66. https://doi.org/10.3390/jpm5020050

61. Lee YK, Chung HH, Kim JW, Park NH, Song YS, Kang SB (2011) Vaginal pH-balanced gel for the control of atrophic vaginitis among breast cancer survivors: a randomized con- trolled trial. Obstet Gynecol 117(4):922-927. https://doi.org/10.1097/ AOG.0b013e3182118790

62. Pitkin RM, VanVoorhis LW (1971) Postirradiation vaginitis. An evaluation of prophylaxis with topical estrogen. Radiology 99(2):417-421 (no abstract available)

63. Singh P, Oehler MK (2010) Hormone replacement after gynaecological cancer. Maturitas 65(3):190-197. https://doi.org/10.1016/j. maturitas.2009;11.017

64. Collaborative Group on Epidemiological Studies of Ovarian Cancer. Menopausal hormone use and ovarian cancer risk: individual participant meta-analysis of 52 epidemiological studies. Lancet 385:1835-42

65. Guidozzi F, Daponte A (1999) Estrogen replacement therapy for ovarian carcinoma survivors: a randomized controlled trial. Cancer 86(6):1013-1018
66. Eeles RA et al (1991) Hormone replacement therapy and survival after surgery for ovarian cancer. BMJ 302(6771):259-262

67. Eeles RA et al (2015) Adjuvant hormone therapy may improve survival in epithelial ovarian cancer: results of the AHT randomized trial. J Clin Oncol 33(35):4138-4144

68. Ursic-Vrscaj M, Bebar S, Zakelj MP (2001) Hormone replacement therapy after invasive ovarian serous cystadenocarcinoma treatment: the effect on survival. Menopause 8(1):70-75

69. Mascarenhas C et al (2006) Use of hormone replacement therapy before and after ovarian cancer diagnosis and ovarian cancer survival. Int J Cancer 119(12):2907-2915

70. AWMF-Registernummer: 032/035OL (2016). S3-Leitlinie Diagnostik, Therapie und Nachsorge maligner Ovarialtumoren, Langversion 2.0. https://leitlinienprogramm-onkologie.de/Ovarialkar zinom.61.0.html

71. Li D, Ding CY, Qiu LH (2015) Postoperative hormone replacement therapy for epithelial ovarian cancer patients: a systematic review and meta-analysis. Gynecol Oncol 139(2):355-362. https ://doi.org/10.1016/j.ygyno.2015.07.109

72. Lin KJ, Cheung WY, Lai JY et al (2012) The effect of estrogen vs. combined estrogen-progestin therapy on the risk of colorectal cancer. Int J Cancer 130:419-430

73. Mørch LS, Lidegaard $\varnothing$, Keiding N, Løkkegaard E, Kjær SK (2016) The influence of hormone therapies on colon and rectal cancer. Eur J Epidemiol 31:481-489. https://doi.org/10.1007/ s10654-016-0116-z

74. Chan JA, Meyerhardt JA, Chan AT, Giovannucci EL, Colditz GA, Fuchs CS (2006) Hormone replacement therapy and survival after colorectal cancer diagnosis. J Clin Oncol 24:5680-5686

75. Coulam CB, Adamson SC, Annegers JF (1986) Incidence of premature ovarian failure. Obstet Gynecol 67:604-606

76. Guttmann H, Weiner Z, Nikolski E, Ish-Shalom S, Itskovitz-Eldor J, Aviram M, Reisner S, Hochberg Z (2001) Choosing an oestrogen replacement therapy in young adult women with Turner syndrome. Clin Endocrinol 54:159-164

77. Langrish JP, Mills NL, Bath LE, Warner P, Webb DJ, Kelnar CJ, Critchley HO, Newby DE, Wallace WH (2009) Cardiovascular effects of physiological and standard sex steroid replacement regimens in premature ovarian failure. Hypertension 53:805-811

Publisher's Note Springer Nature remains neutral with regard to jurisdictional claims in published maps and institutional affiliations. 